left behind as far as could be felt. Patient lost about a pint of blood during removal of the tumour and practically none after it. Patient's pulse became rapid (156/min.) and Liq. Strychn. hypo injection min. 10 given during operation. At the close of the operation pulse was 128 . Wound was brought together without any undue tension by silkworm gut interrupted sutures. Iodoform gauze and white wool applied. Operation lasted 1 hour and 10 minutes. On section the tumour was found to be encapsulatedto be jet black in section-soft in consistency and in one place to have broken down into a cyst. Ulcer led directly into interior of tumour. The tumour was put in weak spirit to be sent to Dr. Ross, of Entebbe.

10 March.-Temp. rose to $101.8^{\circ} \mathrm{F}$. last night. It is subnormal this morning.

14 March.-Wound dressed; it was completely broken downonly two sutures holding. The stitches were all removed and the wound plugged with gauze.

21 March.-The wound has granulated level with surface and is healthily granulating in.

24 March.-Tumour has been pronounced to be a melanotic sarcoma by Dr. Ross, of Entebbe.

28 March.-Healing nicely. Small gland noticed just above wound lying on Poupart's ligament.

5 April.-Eucaine gr. 1 was injected in two doses at intervals of 5 minutes over the small gland referred to in notes (28 March). Incision was made over the latter and three glands removed. The largest was the size of a bean and the other smaller than peas. On section the larger was found to be slightly pigmented. Wound brought together by silkworm sutures and dressings applied.

7 April.-Wound healing by first intention.

11 April.-Stitches removed-first wound nearly healed; second united.

18 April.-Patient allowed to walk.

21 April.-Wound healed under a scab.

28 April.-Patient goes out to-day. To come up in one month's time.

Extract of Letter from Dr. Ross to Dr. Cook

... In sections the most remarkable point is the amount of pigment. This is present in such large quantities that it obscures the finer points. But the chief constituents of the tumour are large spindle cells. These are rather loosely packed and there is a small quantity of fine fibrillary stroma between the cells. There is a tendency to an alveolar arrangement of the spindle cells, but by no means so marked as in typical alveolar sarcoma. Besides the spindle cells there are a few very large giant cells. Most of these are so full of pigment that the nuclei are invisible; in only one was I able to see the nuclei, but these were typical of the malignant giant cell.

There can be no doubt that it is a melanotic sarcoma; whether you add spindle cell, giant cell or mixed cell is merely a matter of taste.

P. H. Ross.

\section{Mengo Hospital 1910, Vol. 2, Page 427, No. 700}

(Reproduced on preceding page)

Name.-Jejefu Omukalazi.

Date of Admittance.-18 May 1910.

Date of Death.-25 May 1910.

Disease.-Sarcoma of jaw.

Religion.-R.C.

History of Present Illness.-Swelling began underneath the jaw one month ago. The eye began to be affected two weeks ago. Parents cupped the swelling and put on Kiganda medicine. No cough.

Previous Illness.-Has had syphilis.

Present Condition.-The growth appears to be nearly half the size of the child's head. Its characters are:

It is firm and elastic. Fixed to the left side of jaw. Extends upwards to zygoma. Downwards nearly to clavicle. To the right it extends beyond midline. The gum is involved on the left side and the teeth are displaced and dropping out.

25 May.-Operation. Child died on the table soon after the operation had commenced.

\section{Mengo Notes 1920, Vol. 5, Page 256}

Name.-Merika. Hospital No. 1137. Admitted 27 June 1920. Diagnosis.-Sarcomata on both ovariẹs.

P.R.-Uterus free and high. Child is thin. Abdomen fullspleen enlarged 3 fingers. Across the lower abdomen is a hard mass and in the right loin a separate rounded mass.

Heart.-Sounds slow and laboured.

Lungs.-N.A.D.

Liver.-Not enlarged. Lymphatic glands of neck and axilla not enlarged.

Operation.-30 June 1920. Large soft tumour reaching from (L) broad ligament to (R) costal margin ? growing from (L) ovary. Another swollen tumour of (R) ovary size of coconut in (R) iliac fossa.

[Part II, with a list of references, will appear next week.]
The establishment, for the past three years, of a Cancer Registry in the University of Ibadan has afforded an opportunity for the detailed study of the tumour whose unique clinical aspects in children in Africa were first adequately described by Burkitt (1958).

Descriptions of the radiological appearances of this tumour, its morbid anatomical distribution, its characteristics on tissue culture, and a consideration of its histopathology in Ibadan have already been given (Cockshott, 1964 ; Edington and Maclean, 1964b ; Edington, Maclean, and Okubadejo, 1964 ; Pulvertaft

* Department of Pathology, University of Ibadan. and Platt, 1964). Briefly, the tumour consists of undifferentiated blast cells with variable numbers of histiocytes present. The peak incidence of the disease is in children aged 5-9 years and the age range extends from 2 to 27 years. In post-mortem material at University College Hospital facial lesions (affecting the jaws or orbit) were found in $28 \%$ of subjects in addition to widespread involvement of other organs. Excluding the facial lesions, the most common presenting forms have been abdominal-especially ovarian tumours in girls-and paravertebral masses, causing paraplegia, in both sexes. The other organs commonly involved have been the kidneys, the heart and mediastinal glands, adrenals, spleen, and abdominal glands, 
Bone-marrow involvement has been present in approximately $15 \%$ of patients (N. Allan, personal communication, 1963 ; E. J. Watson-Williams, personal communication, 1963), but, although blast cells have been detected on buffy-coat examination, a leukaemic blood picture has never been encountered.

\section{Ibadan Cancer Registry}

With the completion of the three-year survey undertaken by the Cancer Registry, it is now possible to calculate from the total figures the relative ratio frequency, the age-specific rates, and the crude rate density of the Burkitt tumour in Ibadan.

Cases recorded in the Cancer Registry come from a number of sources. About one-third of these patients are residents of Ibadan whose illnesses are diagnosed at the University College Hospital or, in smaller numbers, at the local Government Hospital. The remainder of the patients have travelled a varying distance from places in the Western Region and beyond to benefit from the up-to-date medical facilities which Ibadan can provide. Finally, there are a number of histological specimens sent for diagnosis from those mission hospitals in the region which have developed the habit of relying upon the department of pathology at University College Hospital for help in diagnosis. Only patients who are resident in Ibadan were considered when estimating the rate incidence of malignant disease.

\section{Relative Frequency of Different Forms of Malignant Disease in Children}

In the three-year period from the beginning of 1960 to the end of 1962 a total of 1,934 malignant tumours from all sources were recorded in the Registry. Of these, 230 occurred in children aged 0-14 years. Among these the Burkitt tumour far exceeded the others in relative frequency, representing $70 \%$ of all neoplasms in children. At the same time a wide range of other malignant conditions were encountered, including leukaemia. The neoplasms are analysed in terms of relative frequency in Table $I$.

TABLE I.-230 Instances of Malignant Disease in Children aged 0-14 years. Ibadan Cancer Registry, $\star 1960-2$

\begin{tabular}{|c|c|c|c|c|c|c|}
\hline $\begin{array}{l}\text { Int. } \\
\text { Class. No. }\end{array}$ & \multicolumn{4}{|c|}{$\begin{array}{l}\text { Type and Site } \\
\text { of Tumour }\end{array}$} & $\begin{array}{l}\text { No. of } \\
\text { Cases }\end{array}$ & $\begin{array}{l}\% \text { of } \\
\text { Total }\end{array}$ \\
\hline $\begin{array}{l}160 \\
175 \\
178 \\
180 \\
192 \\
193 \\
195 \\
196 \\
197 \\
199 \\
200 \\
200 \cdot 1 \\
201 \\
204\end{array}$ & $\begin{array}{l}\text { Squamous cell car } \\
\text { Ovarian carcinoms } \\
\text { Malignant teratom } \\
\text { Wilms's tumour o } \\
\text { Retinoblastoma } \\
\text { Cerebral tumours } \\
\text { Neuroblastoma .o } \\
\text { Adamantinoma an } \\
\text { Sarcomas of conne } \\
\text { Unspecified malig } \\
\text { Reticulum-cell sar } \\
\text { Burkitt tumour } \\
\text { Hodgkin's disease } \\
\text { Leukaemia }\end{array}$ & 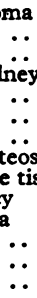 & 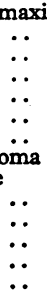 & $\begin{array}{l}\ldots \\
\because \\
\because \\
\ldots \\
\because \\
\because \\
\because \\
\because \\
\therefore\end{array}$ & $\begin{aligned} 1 \\
1 \\
1 \\
14 \\
14 \\
8 \\
3 \\
3 \\
4 \\
4 \\
10 \\
2 \\
4 \\
161 \\
5 \\
13\end{aligned}$ & $\begin{array}{r}0.4 \\
0.4 \\
0.4 \\
6.0 \\
3.5 \\
1.3 \\
1.3 \\
1.7 \\
4.3 \\
0.9 \\
1.7 \\
70.0 \\
2.2 \\
5.7\end{array}$ \\
\hline
\end{tabular}

\section{Incidence of the Burkitt Tumour in Ibadan}

For calculations of rate incidence the 56 instances of the Burkitt tumour diagnosed in patients from the city of Ibadan during the three-year period April, 1960, to March, 1963, have been considered. The population of Ibadan was estimated on the basis of a W.H.O. random sample undertaken in the course of a tuberculosis survey, and the results of sampling have been applied to the total figure for the population of Ibadan $(479,000)$. The 1962 Nigerian national census, during which this total figure was obtained, eventually broke down, but it has been possible, with the information available, to make an estimate of the population at risk, using five-year age-groupings up to the age of 19 and ten-year groupings thereafter.
Table II indicates the age-specific rate per 100,000 of the population. The figure for all ages represents the crude incidence rate.

TABLE II.-Incidence of the Burkitt Tumour per 100,000 of the Population of Ibadan (April, 1960-March, 1963) Compared with the Mortality Incidence of Leukaemia in American Negro Children and Adolescents (1958-9)

\begin{tabular}{|c|c|c|c|c|c|c|c|c|}
\hline & \multirow{2}{*}{\multicolumn{2}{|c|}{$\begin{array}{l}\text { Estimated } \\
\text { Ibadan } \\
\text { Population }\end{array}$}} & \multicolumn{4}{|c|}{ Ibadan } & \multicolumn{2}{|c|}{ U.S. Non-White } \\
\hline & & & \multicolumn{4}{|c|}{ The Burkitt Tumour } & \multicolumn{2}{|c|}{ Leukaemia } \\
\hline & \multirow[b]{2}{*}{$\mathbf{M}$} & \multirow[b]{2}{*}{$\mathbf{F}$} & \multicolumn{2}{|c|}{$\mathbf{M}$} & \multicolumn{2}{|r|}{$\mathbf{F}$} & $\mathbf{M}$ & $\mathbf{F}$ \\
\hline & & & $\begin{array}{l}\text { Cases } \\
\text { (3 yrs) }\end{array}$ & \begin{tabular}{|c|} 
Age- \\
specific \\
Rate \\
(Annual)
\end{tabular} & $\begin{array}{l}\text { Cases } \\
\text { (3 yrs) }\end{array}$ & $\mid \begin{array}{c}\text { Age- } \\
\text { specific } \\
\text { Rate } \\
\text { (Annual) }\end{array}$ & $\begin{array}{c}\text { Age- } \\
\text { specific } \\
\text { Mortality } \\
\text { Rate }\end{array}$ & $\begin{array}{c}\text { Age- } \\
\text { specific } \\
\text { Mortality } \\
\text { Rate }\end{array}$ \\
\hline $\begin{array}{c}\text { All ages } \\
0-4 \\
5-9 \\
10-14 \\
15-19 \\
20-29 \\
30+\end{array}$ & $\begin{array}{r}237,000 \\
40,000 \\
29,000 \\
24,000 \\
22,000 \\
45,000\end{array}$ & $\begin{array}{r}242,000 \\
40,000 \\
34,000 \\
23,000 \\
15,000 \\
52,000\end{array}$ & $\begin{array}{r}36 \\
3 \\
19 \\
11 \\
1 \\
2 \\
0\end{array}$ & $\begin{array}{r}5.1 \\
2.5 \\
21.8 \\
15.3 \\
1.5 \\
1.5 \\
0.0\end{array}$ & $\begin{array}{r}20 \\
1 \\
10 \\
7 \\
2 \\
0 \\
0\end{array}$ & $\begin{array}{r}2.8 \\
0.8 \\
9.8 \\
10.1 \\
4.4 \\
0.0 \\
0.0\end{array}$ & $\begin{array}{l}4.6 \\
2.7 \\
1.7 \\
1.7 \\
2.2\end{array}$ & $\begin{array}{l}3.6 \\
2.6 \\
1.7 \\
1.8 \\
2.1\end{array}$ \\
\hline
\end{tabular}

The incidence of leukaemia in children is low in East and West Africa (Davies, 1960 ; Edington and Maclean, 1964a), and it has been suggested that the Burkitt tumour might be a variable expression of leukaemia in African children. It is interesting, therefore, to compare these figures with the age-specific mortality incidence of leukaemia in American negro children and adolescents. It will be noted that the Burkitt tumour in Ibadan seems to be very much more common than is leukaemia among negroes in the same age-groups in the U.S.A.

In terms of relative frequency, the Burkitt tumour has been the second commonest form of malignant disease to be diagnosed in Ibadan in recent years, being exceeded in frequency only by carcinoma of the cervix uteri.

\section{Discussion}

References to what can now be recognized as the Burkitt tumour appear in the West African literature from 1934 onwards (Smith and Elmes, 1934 ; Elmes and Baldwin, 1947 ; De Smet, 1956 ; Edington, 1956 ; Thijs, 1957 ; Sankale et al., 1958). Regarding Nigeria, Smith and Elmes, analysing 500 tumours from Lagos, noted 10 round-cell sarcomas of the orbit in children under 10 years of age and also included in their series, in the same age-group, two sarcomas of the testis, a round-cell sarcoma of the ovary and lymphosarcoma of both mediastinum and abdomen. Subsequently Elmes and Baldwin (1947) reviewed 1,000 tumours from Lagos, among which they described 29 sarcomas of the facial area.

Conclusions regarding the incidence of any particular tumour which are based on relative ratio frequencies alone are, however, unreliable and can be confirmed only by observations made on a population of known size. Even when this is done, as in Ibadan, diagnoses made under existing conditions must in the majority of instances depend upon patients attending one or other of the two available hospitals. It is well known that native forms of treatment are still widely used by the local population in conjunction with, or as an alternative to, modern medicine. It cannot be claimed, therefore, that this survey will have succeeded in detecting all patients suffering from a particular malignant disease in Ibadan, but the figures should at least indicate minimal density rates.

With these considerations in mind, there can no longer be any doubt of the common occurrence of the Burkitt tumour in West as well as in East Africa. This is a condition which is apt to afflict at least 15 among every 100,000 children aged 5 to 9 years in Ibadan. Among malignant diseases of children in this area the importance of the Burkitt tumours far outstrips that of any other neoplasm. 
Undoubtedly a neoplasm, this fatal condition still causes much discussion about whether it should or should not be regarded as a tumour of the reticuloendothelial system. Although its distribution is unusual and exceptionally extensive it does mimic most closely the distribution of multiple myeloma. It also has certain resemblances to chloroma. So far as our present knowledge goes it would seem reasonable therefore to continue to classify it among the reticuloendothelial tumours.

It is extremely difficult to decide whether the tumour is multicentric or unicentric. In a number of instances in Ibadan widespread involvement of bone-marrow has been found, although, in our experience, the disease never evolves into leukaemia. On the other hand, the association of ovarian and kidney deposits and the association of cardiac and mediastinal gland deposits would tend to favour metastatic spread. Our general impression is that in the early stages the tumour is unicentric. Burkitt (1962) has suggested that the altitude and temperature of the areas in Africa where the tumour has been recorded, and its age incidence, are factors which are suggestive of an arthropod-borne causal agent-possibly viral. The age incidence recorded in Ibadan is similar to that recorded in East Africa, and would once again, perhaps, favour an agent affecting young children to which immunity is gained later in childhood by the majority of the population. These remarks are, of course, at present purely speculative and much intensive research remains to be done on all aspects of this tumour, which is so distressingly frequent in many parts of Africa.

\section{Summary}

The crude and age-specific rates of the Burkitt tumour in Ibadan, Western Nigeria, have been assessed. When all age- groups were considered the tumour was found to be second in incidence only to carcinoma of the cervix, and it was by far the most common malignancy seen in childhood, being many times more common than leukaemia in the American negro in comparable age-groups.

Acknowledgments are due to the British Empire Cancer Campaign, which has supported the work of the Ibadan Cancer Registry with a generous grant ; to Professor J. Knowelden for advice; to Dr. Han, of the W.H.O. Tuberculosis Survey, for permission to use population data ; and to the clinicians of University College Hospital and Adeoyo. Hospital for notifying cases of the Burkitt tumour to the Registry.

\section{REFERENCES}

Burkitt, D. (1958). Brit. 7. Surg., 46, 218.

(1962). Ann. roy. Coll. Surg. Engl., 30, 211.

Cockshott, W. P. (1964). Symposium on Tumours of the Reticuloendothelial System in Africa. Sponsored by U.I.C.C. Paris (February, 1963). In press.

Davies, J. N. P. (1960). Acta Un. int. Cancr., 16, 1618.

De Smet, M. P. (1956). Ann. Soc. belge Méd. trop., 36, 53.

Edington, G. M. (1956). Brit. F. Cancer, 10, 595.

- and Maclean, C. M. U. (1964a). Leukaemia in Ibadan, Nigeria. Int. Soc. Geog. Path. Milan, 1963. In press.

- (1964b). Symposium on Tumours of the Reticulo-endothelial System in Africa. Sponsored by U.I.C.C. Paris (February, 1963). In press.

- and Okubadejo, O. A. (1964). Ibid.

Elmes, B. G. T., and Baldwin, R. B. T. (1947). Ann. trop. Med. Parasit., 41,321 .

Pulvertaft, R. J. V., and Platt, H. (1964). Symposium on Tumours of the Reticulo-endothelial System in Africa. Sponsored by U.I.C.C. Paris (February, 1963). In press.

Sankale, M., Le Viguellioux, J., Oliveau-Lebreton, G., and Milhade, J. (1958). Sem. Hôp. Paris, 34, 2680.

Smith, E. C., and Elmes, B. G. T. (1934). Ann. trop. Med. Parasit., 28, 461 .

Thijs, A. (1957). Ann. Soc. belge Méd. trop., 37, 483.

\title{
Lessons Derived From Ten Years' Experience of the Special Baby-care Unit in a Maternity Hospital
}

\author{
W. S. CRAIG, ${ }^{*}$ M.D., F.R.C.P., F.R.C.P.ED., F.R.S.ED. ; M. PATTULLO, † S.R.N., s.C.M.
}

Special baby-care units have been established in a number of maternity hospitals, and their development is referred to in a report published by the Ministry of Health (1961). These units have been described as "everywhere a great success, as welcome to domiciliary midwifery as to the parent unit" (Pugh, 1962). As an integrated part of the hospital, a baby-care unit is subject to the influence of changes in general hospital policy; and administrative, clinical, and teaching aspects of the work of such a unit have to be adjusted from time to time. This paper reviews the lessons learned during the first 10 years of a special baby-care unit established in 1952 .

\section{The Unit}

The accommodation consists of rooms adapted to provide three nurseries containing five, five, and six cots, and three cubicles each intended for a mother and her baby. For reasons given later, use of the cubicles has been reserved since 1958

\footnotetext{
« Professor of Paediatrics and Child Health, University of Leeds.

+ Honorary Instructor in Nursing Care of the Newborn, Department of Paediatrics and Child Health, University of Leeds.
}

for babies only, the total number of cots thus being increased to 24 .

Authorized establishment consists of four trained midwives, including the departmental sister in charge. Each pupil midwife taking her Part I training in the hospital is attached to the special baby unit for a period of two weeks. The number of pupil midwives working in the unit at any one time has varied from two to six. Invaluable service has been given by nonresident sick children's trained nurses, enrolled nurses, and nursery nurses who have been members of the staff at different times. Medical supervision is provided by a resident senior house officer and by visiting paediatricians. Liaison with local health authorities is maintained along the lines previously described (Craig et al., 1951). When requested by the obstetrician or labour-ward sister, the senior house officer and senior sister of the baby unit are present at the birth of a baby in the labour ward.

During the 10 years 4,412 babies were admitted to the unit, including 786 born outside the hospital. This article is concerned with the 3,626 infants born in hospital and transferred to the baby unit from the labour ward, the lying-in wards, or 